\title{
Mid-ocean exchange of container vessel ballast water. 1: Seasonal factors affecting the transport of harmful diatoms and dinoflagellates
}

\author{
Fangzhu Zhang, Mike Dickman*
}

Department of Ecology \& Biodiversity, The University of Hong Kong, Hong Kong, China

\begin{abstract}
Our study of 34 ships (20 direct from Oakland, California, USA, and 14 more after open ocean exchange) is the first year-long seasonal study to assess the effectiveness of open ocean exchange of ballast waters. The highest number of harmful species occurred in April and February when water temperatures in Hong Kong (China) and Oakland were low. The periods with the greatest species richness of harmful species did not correspond to periods with the highest abundance of harmful species. The latter occurred in early September and mid-August, when Skeletonema costatum $\left(14000\right.$ cells $\left.~^{-1}\right)$ dominated the plankton in the ballast water from Oakland Harbor. From April 1996 to April 1997, ballast water samples were collected from 34 Orient Overseas Container Lines Ltd ships which took 16 d to travel from Oakland to Hong Kong. Of the 34 ships, 14 exchanged their Oakland Harbor ballast water for open ocean water (referred to here as reballasting). Open ocean was defined as waters with a depth $>2000 \mathrm{~m}$. Once reballasting was completed, the contents of ballast tank no. 1 were not discharged until the ship reached Hong Kong. Six harmful diatoms and 9 harmful dinoflagellate species were observed in the ballast water from Oakland Harbor. These included the diatom Chaetoceros concavicornis and the PSP (paralytic shellfish poisoning) toxin producing dinoflagellate Alexandrium catenella. Of the 15 harmful species found in the Oakland Harbor ballast water, $8(53 \%)$ were also found in the ballast water of ships that had exchanged coastal for open ocean ballast water. The abundance of harmful species in open ocean ballast water was $87 \%$ lower than those in the ballast water from Oakland Harbor. The reason that mid-ocean exchange failed to eliminate all harmful diatoms and dinoflagellates was probably because the ballast tank was never completely emptied before it was reballasted with mid-ocean water
\end{abstract}

KEY WORDS: Ballast water - Mid-ocean exchange $\cdot$ Harmful species - Diatoms - Dinoflagellates Container ships - Seasonal variation

\section{INTRODUCTION}

The global movement of ballast water by ships appears to be the largest single vector for non-indigenous species transfers (Ruiz et al. 1997). The ballast water of most container ships is stored in dedicated ballast tanks and is used to trim and stabilise the vessel and to improve its manoeuvrability when cargo is absent (Hutchings 1992). On arrival at their destination, these ships discharge their ballast water into the port waters as cargo is loaded. The discharged ballast

- Addressee for correspondence

E-mail:dickman@hkusua.hku.hk water mixes with the receiving waters and, if the environmental conditions are appropriate, some of the discharged individuals in the ballast water may reproduce and colonise the receiving waters. In time, these newly released species may disperse to areas quite distant from the cargo port. A wide variety of marine organisms including fish, invertebrates, bacteria, seaweed and algae have been introduced into new environments through ballast water discharges (e.g. Carlton 1985, Jones 1991, Mills et al. 1993, McCarthy \& Khambaty 1994, Gosselin et al. 1995). The introductions of exotic (non-indigenous) species, especially harmful organisms, can have impacts on human health and the aquatic ecosystems and on aquaculture and other industries, with financial consequences (e.g. 
Hebert et al. 1989, Carlton \& Geller 1993, Rigby et al 1995, Chu et al. 1997).

The substantial increase in the size and number of container ships, the increase in their speed and the increase in eutrophication of many coastal waters makes it more likely for harmful species to be transferred across oceanic boundaries (Hallegraeff \& Bolch 1992). The present study compares the number of harmful algae in ballast water from Oakland Harbor, California, USA, with the number in ballast water after open ocean exchange. It does not provide any information on phytoplankton viability in a ship's ballast water tanks as this would have required us to attempt to culture each of the many species we studied. Instead we preserved the samples in Lugol's iodine solution and counted cells with intact chloroplasts, ignoring empty cells or cells with decomposing chloroplast structures.

It is estimated that about 10 billion tonnes of ballast water is transported around the world each year (Rigby et al. 1995); as a result, ballast water has been regarded as an international pollutant of major consequence (Rigby et al. 1993, 1995). Mid-ocean exchange was recommended in the ballast water control guidelines of the International Maritime Organisation (IMO) as a cost-effective and environmentally friendly method of coastal water treatment (Rigby \& Hallegraeff 1996). The terms 'mid-ocean exchange' and 'open ocean exchange' are used in this paper to denote the emptying of the ballast water tanks and subsequent refilling with open ocean water. The term 'flushing' is used here to denote ballast water exchange by the passing of open ocean water through a filled ballast water tank. For ships sampled in the present study, we were informed that only open ocean exchange was carried out and not 'flushing'. We were informed that viewing the bottom of the ballast tank to determine how much sediment was present was only possible when the tank was empty. At no time were the tanks emptied to permit us to view them.

In contrast to coastal and estuarine waters, midocean waters are poor in nutrients and contain relatively few organisms. These mid-ocean organisms are regarded as unlikely to adapt easily to coastal environments (Williams et al. 1988). Many studies of the effectiveness of mid-ocean exchange are made by comparing the number of viable individuals in the ballast water at the start and end of a ship's cruise. We took a different approach and compared the number of individuals in 2 kinds of ballast water only at the end of a ship's cruise. These 2 kinds of ballast water were sampled: water from ships that had sailed to Hong Kong (China) without discharging their Oakland Harbor ballast water and those which discharged it and took on open ocean water in its place. In both cases, this was done during a $16 \mathrm{~d}$ cruise period.

In the present year-long study, ballast water samples were repeatedly collected from the same container ships and these ships followed roughly the same route each time they travelled from Oakland to Hong Kong (Fig. 1). The purpose of our study was to examine the effectiveness of mid-ocean exchange in controlling the abundance of harmful diatoms and dinoflagellates released into Hong Kong waters.

Open ocean or mid-ocean exchange occurs when surface waters from parts of the ocean having depths greater than $2000 \mathrm{~m}$ are taken on in exchange for coastal ballast waters pumped into the open sea. If the seas are not too rough, each ballast tank can be individually emptied and then filled with oceanic waters. In rough water, reballasting in this manner is not recommended as ships with empty ballast tanks are at risk of breaking up in heavy seas (Thompson Clarke Shipping 1993). Alternatively, while coastal ballast water in a ballast tank is being pumped into the open ocean, that same ballast tank can be filled with open ocean water by 'flushing'.

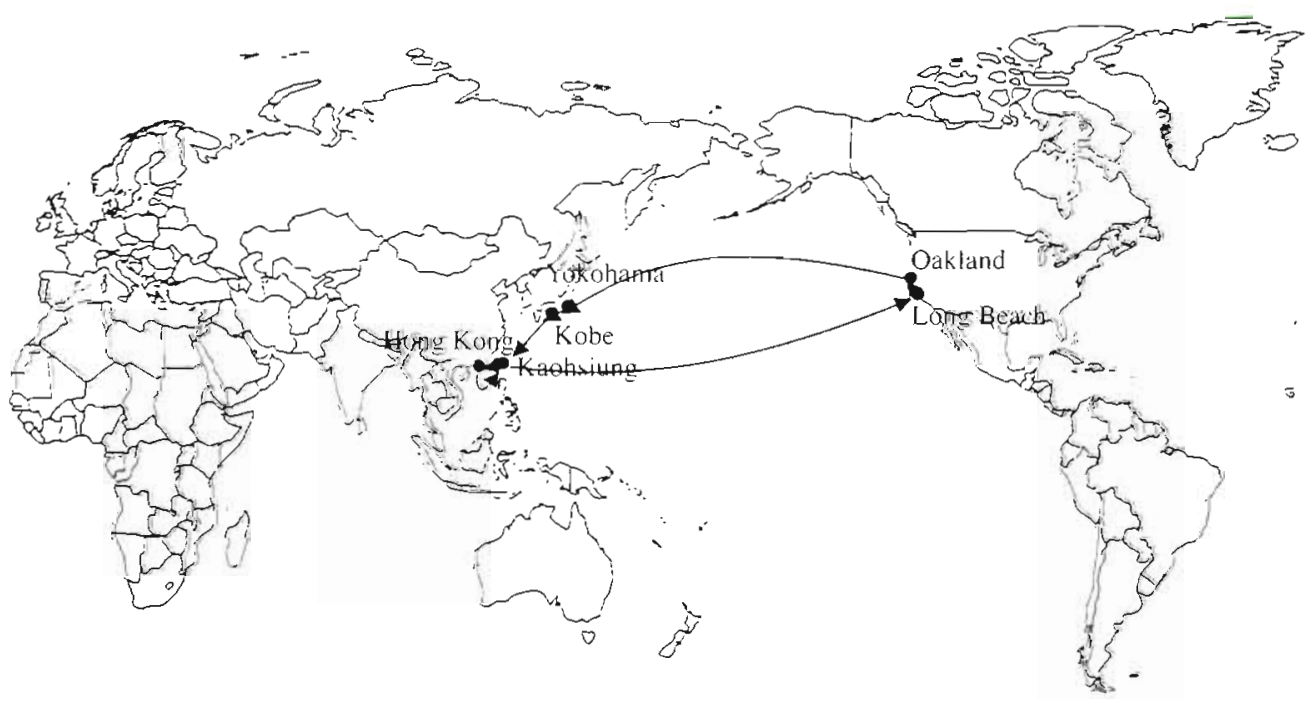

Fig. 1 Route followed in $1996-1997$ by Orient Overseas Container Lines Ltd (OOCL) ships leaving Oakland Harbor, California, USA, en route to Yokohama and Kobe, Japan, Kaohsiung, Taiwan, Hong Kong, China, Kaohsiung and Long Beach, California. The trip from Oakland to Hong Kong averaged about $16 \mathrm{~d}$ 


\section{METHODS}

Sample collection. There were 5 Orient Overseas Container Lines Ltd (OOCL) ships involved in the present study. These ships travelled from Oakland, California, to Yokohama and Kobe, Japan, then to Kaohsiung, Taiwan, and Hong Kong. It takes about $16 \mathrm{~d}$ to travel from Oakland to Hong Kong. On their return trip they travel to Kaohsiung and Long Beach (Fig. 1).

Three OOCL vessels ('America', 'California' and 'Japan') carried the ballast water directly from Oakland to Hong Kong without stopping for open ocean exchange of ballast water Two other vessels ('China' and 'Hong Kong') discharged their Oakland coastal ballast water from tank no. 1 into the Pacific Ocean and refilled ballast tank no. 1 with water taken from the open ocean. In the process of reballasting in the open ocean, about 1 to $5 \%$ of the Oakland Harbor water was retained due to the incomplete emptying of the ballast tank (Captain Li Wai Man pers comm.). Normally, the ballast water exchange took place after the ships had been traveling for about $24 \mathrm{~h}$, weather permitting. The Oakland departure dates and Hong Kong arrival dates for the 2 OOCL ships whirh carried out open ocean exchange en route to Hong Kong are provided in Table 1. For the sake of consistency, only the bow ballast water tank (ballast tank no. 1) was used in this study.

Before any sampling took place, the ballast water from tank no. 1 was pumped for several minutes to insure that the water in the line was ballast water from tank no. 1. A small volume flowmeter was connected to a small line leading from the ballast water discharge pipe to a $10 \mu \mathrm{m}$ mesh plankton net. After $100 \mathrm{l}$ of water was allowed to pass through the plankton net, about $50 \mathrm{ml}$ of concentrate remained in the collection bottle at the cod end of the net. This was transferred to a
$100 \mathrm{ml}$ plastic vial. The concentrate was preserved in Lugol's iodine solution. The $50 \mathrm{ml}$ preserved sample was further concentrated to $20 \mathrm{ml}$ on the next day by decanting the top $30 \mathrm{ml}$ of the sample. Between April 1996 and April 1997, 14 and 20 ballast water samples from OOCL ships sailing from Oakland Harbor which did and did not, respectively, reballast in the open ocean were collected.

Cell counts. A small amount $(0.025 \mathrm{ml})$ of the concentrated sample was put on a slide under an $18 \times$ $18 \mathrm{~mm}$ coverslip. The algae on the slide were observed using an Olympus research microscope. Only diatoms and dinoflagellates were recorded. Species were identified using the following references: Cheng et al. (1996), Fukuyo et al. (1990), Hallegraeff (1991), Halse \& Fryxell (1995), Jin et al. (1985, 1992), Larsen \& Moestrup (1989), Taylor et al. (1995), Tomas (1996) and Yamaji (1984). Three replicate slides were counted to assess counting error When the abundance of algae was low, 4 or more slides were counted until a minimum of 500 individuals had been counted for each sample. The density of each algal species was calculated by multiplying the average number counted by 8 to give the number of individuals sampled per litre of ballast water. Samples were also analysed using a scanning electron microscope (SEM) for algal identification in order to determine the abundance of harmful species of diatoms and dinoflagellates.

\section{RESULTS}

Over the survey year, there were 90 diatom species and 17 dinoflagellate species observed in Oakland Harbor ballast water (OHBW), while 69 diatom species and 9 dinoflagellate species were observed in the open

Table 1. Mid-ocean ballast water exchange of ships (Orient Overseas Container Lines Ltd, OOCL) sampled in this study for harmful diatoms and dinoflagellates in ballast tank no. 1

\begin{tabular}{|c|c|c|c|c|c|}
\hline Sample date & Vessel name & Voyage dates & Ballast water exchange & Latitude & Longitude \\
\hline 9 Jun 1996 & OOCL 'Hong Kong' & 23 May-8 Jun & $25 \mathrm{May}$ & $38^{\circ} 53^{\prime} \mathrm{N}$ & $143^{\circ} 30^{\prime} \mathrm{W}$ \\
\hline 23 Jun 1996 & OOCL 'China' & 6 Jun-22 Jun & 8 Jun & $37^{\circ} 23^{\prime} \mathrm{N}$ & $148^{\circ} 29^{\prime} \mathrm{W}$ \\
\hline 14 Jul 1996 & OOCL 'Hong Kong' & 27 Jun-13 Jul & $28 \mathrm{Jun}$ & $41^{\circ} 32^{\prime} \mathrm{N}$ & $129^{\circ} 15^{\prime} \mathrm{W}$ \\
\hline 28 Jul 1996 & OOCL 'China' & $11 \mathrm{Jul}-27 \mathrm{Jul}$ & $12 \mathrm{Ju}]$ & $40^{\circ} 51^{\prime} \mathrm{N}$ & $131^{\circ} 09^{\prime} \mathrm{W}$ \\
\hline 18 Aug 1996 & OOCL 'Hong Kong' & 1 Aug-17 Aug & 3 Aug & $42^{\circ} 57^{\prime} \mathrm{N}$ & $135^{\circ} 15^{\prime} \mathrm{W}$ \\
\hline 6 Oct 1996 & OOCL 'China' & $20 \mathrm{Sep}-5 \mathrm{Oct}$ & $27 \mathrm{Sep}$ & $46^{\circ} 14^{\prime} \mathrm{N}$ & $153^{\circ} 12^{\prime} \mathrm{E}$ \\
\hline 27 Oct 1996 & OOCL 'Hong Kong' & 11 Oct -27 Oct & 12 Oct & $37^{\circ} 55^{\prime} \mathrm{N}$ & $151^{\circ} 12^{\prime} \mathrm{W}$ \\
\hline 10 Nov 1996 & OOCL 'China' & 24 Oct-9 Nov & 29 Oct & $40^{\circ} 42^{\prime} \mathrm{N}$ & $176^{\circ} 07^{\prime} \mathrm{W}$ \\
\hline 1 Dec 1996 & OOCL 'Hong Kong' & $14 \mathrm{Nov}-30 \mathrm{Nov}$ & 16 Nov & $40^{\circ} 49^{\prime} \mathrm{N}$ & $129^{\circ} 36^{\prime} \mathrm{W}$ \\
\hline 14 Dec 1996 & OOCL 'China' & $1 \mathrm{Dec}-14 \mathrm{Dec}$ & $3 \mathrm{Dec}$ & $36^{\circ} 58^{\prime} \mathrm{N}$ & $164^{\circ} 52^{\prime} \mathrm{W}$ \\
\hline $4 \operatorname{San} 1997$ & OOCL 'Hong Kong' & $19 \mathrm{Dec}-4 \mathrm{Jan}$ & $21 \mathrm{Dec}$ & $41^{\circ} 47^{\prime} \mathrm{N}$ & $126^{\circ} 48^{\prime} \mathrm{W}$ \\
\hline $16 \operatorname{Mar} 1997$ & OOCL 'Hong Kong' & $28 \mathrm{Feb}-15 \mathrm{Mar}$ & $8 \mathrm{Mar}$ & $36^{\circ} 39^{\prime} \mathrm{N}$ & $157^{\circ} 00^{\prime} E$ \\
\hline $30 \operatorname{Mar} 1997$ & OOCL 'China' & $13 \mathrm{Mar}-29 \mathrm{Mar}$ & $16 \mathrm{Mar}$ & $47^{\circ} 45^{\prime} \mathrm{N}$ & $135^{\circ} 58^{\prime} \mathrm{W}$ \\
\hline 20 Apr 1997 & OOCL 'Hong Kong' & $3 \mathrm{Apr}-20 \mathrm{Apr}$ & $11 \mathrm{Apr}$ & $49^{\circ} 58^{\prime} \mathrm{N}$ & $160^{\circ} 09^{\prime} \mathrm{E}$ \\
\hline
\end{tabular}




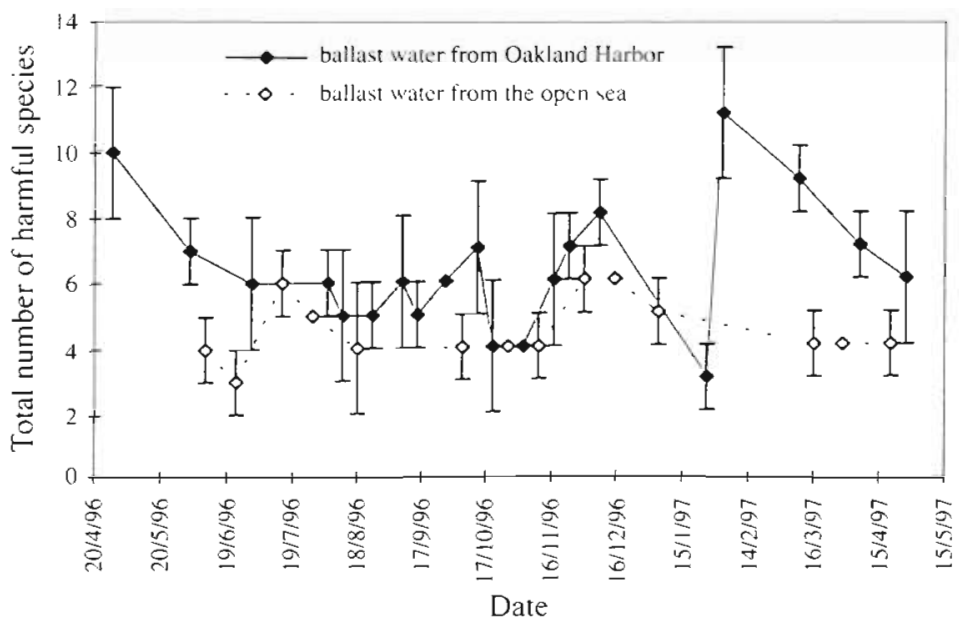

Fig. 2. Seasonal changes in the total number of harmful diatoms and dinoflagellates in open ocean and Oakland Harbor water transported Harbor during the year-long study. Dates given as $\mathrm{d} / \mathrm{mo} / \mathrm{yr}$ in ballast tank no. 1 by ships travelling to Hong Kong from Oakland

\section{Seasonal variation in the abundance of harmful species}

The seasonal abundances of potentially toxic species, such as Pseudonitzschia species (Fig. 3) and the PSP (paralytic shellfish poisoning) toxin producing dinoflagellate Alexandrium catenella (Fig. 4), in the ballast water from Oakland Harbor as it arrived in Hong Kong indicate that each peaked in abundance at different times of the year. The abundance of Pseudonitzschia species in the open ocean ballast remained low throughout the year. $A$. catenella (Fig. 4) was never found in the open ocean ballast water It was most abundant in the OHBW in April but its abundance never exceeded 50 cells $\mathrm{l}^{-1}$ (Fig. 4).

Only 2 species of potentially toxic diatoms were observed in the ballast water of OOCL vessels in Hong Kong: Pseudonitzschia multiseries Hasle and $P$. pseudodelicatissima (Hasle) Hasle. Both have been reported to ocean ballast water (OOBW). Diatoms such as Skeletonema costatum, Pseudonitzschia spp., Chaetoceros spp., and Thalassiosira spp. were the most common. Fifteen harmful species were found in the OHBW over the study period and 8 harmful species were found in the OOBW samples (Fig. 2, Table 2). The total abundance of harmful species in the OOBW was significantly lower than that in OHBW ( $\mathrm{p}<0.001, \mathrm{n}=34$ ). contain domoic acid (amnesic shellfish poisoning, ASP). $P$. multiseries and $P$. pseudodelicatissima were first described in Hong Kong waters by Dickman (1996) and Dickman et al. (1997). In addition to these 2 potentially toxic species, 2 non-toxic species of Pseudonitzschia were observed ( $P$. pungens and $P$. multistriata). $P$. pungens was the most commonly observed species in our ballast water samples. $P$. multi-

Table 2. Abundance and frequency of harmful species (diatoms and dinoflagellates) recorded in the ballast water samples

\begin{tabular}{|c|c|c|c|c|}
\hline \multirow[t]{2}{*}{ Species name } & \multicolumn{2}{|c|}{ Ballast water from Oakland Harbor } & \multicolumn{2}{|c|}{ Ballast water from the open ocean } \\
\hline & $\begin{array}{l}\text { Abundance } \\
\text { (cells } 1^{-1} \text { ) }\end{array}$ & $\begin{array}{l}\text { Frequency } \\
\text { (20 ships) }\end{array}$ & $\begin{array}{l}\text { Abundance } \\
\text { (cells } ~^{-1} \text { ) }\end{array}$ & $\begin{array}{l}\text { Frequency } \\
\text { (14 ships) }\end{array}$ \\
\hline \multicolumn{5}{|l|}{ Diatoms } \\
\hline Asterionellopsis glacialis (Castracane) Round & 101 & 11 & 10 & 9 \\
\hline Chaetoceros atlanticus Cleve & 17 & 5 & 13 & 7 \\
\hline Chaetoceros decipiens Cleve & 13 & 2 & 0 & 0 \\
\hline Chaetoceros concavicornis Mangin & 15 & 7 & 0 & 0 \\
\hline Pseudonitzschiaspp. & 366 & 20 & 78 & 14 \\
\hline Skeletonema costatum (Greville) Cleve & 3668 & 20 & 434 & 14 \\
\hline \multicolumn{5}{|l|}{ Dinoflagellates } \\
\hline Alexandrium catenella (Whedon \& Kofoid) Balech & 7 & 11 & 0 & 0 \\
\hline Ceratium fusus (Ehrenberg) Dujardin & 1.4 & 5 & 1.4 & 4 \\
\hline Dinophysis caudata Saville-Kent & 4 & 3 & 0 & $\hat{0}$ \\
\hline Gymnodinium sp. (Midorishio) & 2 & 2 & 0 & 0 \\
\hline Prorocentrum balticum (Lohmann) Loeblich III & 3 & 2 & 0 & 0 \\
\hline Prorocentrum micans Ehrenberg & 15 & 14 & 7 & 9 \\
\hline Prorocentrum minimum (Pavillard) Schiller & 4 & 6 & 0.2 & 1 \\
\hline Prorocentrum sigmoides Bohm & 3 & 5 & 0 & 0 \\
\hline Scrippsiella trochoidea Schiller & 15 & 12 & 4 & 3 \\
\hline Total & 4235 & $15^{\mathrm{d}}$ & 550 & $8^{a}$ \\
\hline
\end{tabular}


striata was observed for the first time in southern China by Y. Qi \& L. Zheng (unpubl. data).

Because identification of the different species of Pseudonitzschia necessitates the use of an SEM, the SEM photomicrographs of the 4 species noted above are included here (Fig. $5 \bar{a}-\mathrm{f}$ ).

The seasonal variation in the abundance of all harmful species (diatoms and dinoflagellates) peaked in late summer (Fig. 6). The total annual abundance of harmful phytoplankton in the OOBW (550 cells $\mathrm{l}^{-1}$ ) was significantly lower than that in OHBW (4235 cells $\left.\mathrm{l}^{-1}\right)(\mathrm{p}<0.001, \mathrm{n}=34)$. Thus, the OOBW exchange was $87 \%$ effective in reducing the abundance of the harmful diatoms and dinoflagellates. That is to say $\left(1-\left[550\right.\right.$ cells $1^{-1}$ in the OOBW/4235 cells $\mathrm{l}^{-1}$ in the OHBW] $=87 \%$ ). The OOBW exchange was $83 \%$ effective in reducing the total abundance of diatoms and dinoflagellates

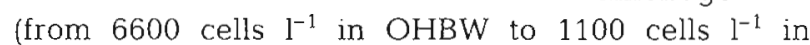
OOBW)

\section{DISCUSSION}

\section{Harmful dialoms}

Some species of Pseudonitzschia are reported to produce ASP (Hasle 1994, Dickman \& Glenwright 1997). In our year-long study, $P$. pungens (Fig. 5a) was the most commonly observed species of this genus in the ballast water of OOCL container ships from Oakland Harbor. $P$. pseudodelicatissima (Fig. 5b) is reported to

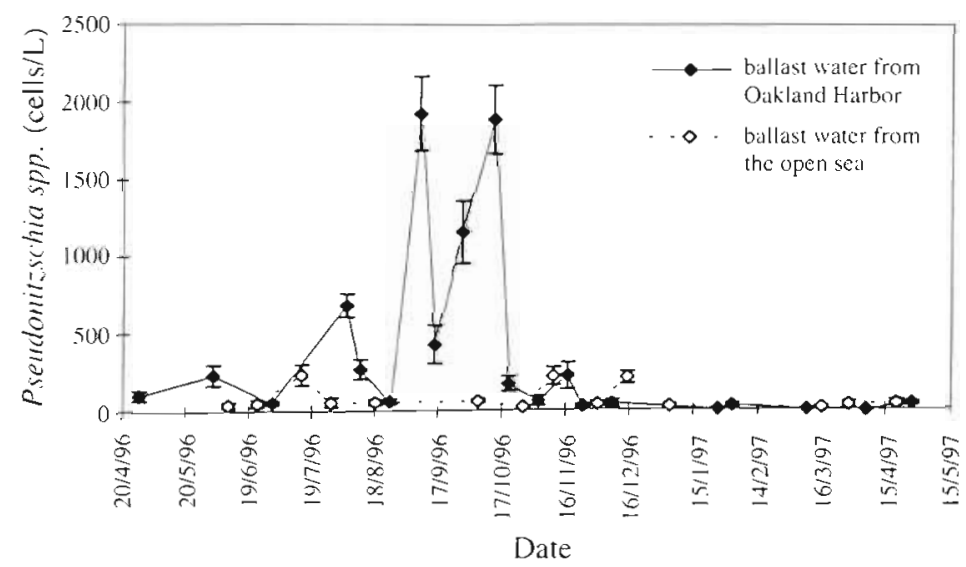

Fig. 3. Seasonal changes in the number of species transported in the water in ballast tank no. 1 from Oakland Harbor and from the open ocean during the year-long study. Dates given as $\mathrm{d} / \mathrm{mo} / \mathrm{yr}$ produce domoic acid; however, this is not always the case. Plankton tows from one area of the Bay of Fundy, Canada, contained $P$. pseudodelicatissima which produced domoic acid while tows from another area of the Bay of Fundy contained $P$. pseudodelicatissima which did not (Haya et al. 1991). P. pseudodelicatissima is distinguished from $P$. pungens by its central pseudonodulus (central nodule) and its 4 to 6 rows of intercostal poroids with 10 to 13 poroids $\mu^{-1}$ and 10 to 13 fibulae (keel punctae) every $10 \mu \mathrm{m}$. P. multistriata (Fig. 5c) looks like P. pseudodelicatissima (35 to $40 \mu \mathrm{m}$ long by $2.5 \mu \mathrm{m}$ wide at its widest point) under the light microscope. However, P. multistriata does not display a pseudonodulus (central nodule) and has 2 rows of intercostal poroids with 8 to 10 poroids every $10 \mu \mathrm{m}$, 25 fibulae (keel punctae) every $10 \mu \mathrm{m}$ and 36 to 40 costae every $10 \mu \mathrm{m}$. There are no reports of this species producing ASP.

Pseudonitzschia multiseries can be a source of ASP (Garrison et al. 1992, Villac et al. 1993). This toxic species has been reported in the Atlantic waters of North America, Europe and South America and in the Pacific waters of North America and Northeast Asia (Garrison et al. 1992, Villac et al. 1993). It was positively identified from OHBW from SEM photomicrographs (Fig. 5d, e). Another potentially toxic species, $P$. delicatissima, (Fig. 5f) was observed in the OHBW on only 2 occasions. In general, Pseudonitzschia spp. were $78 \%$ more abundant in OHBW than in OOBW ( $\mathrm{p}<0.01$ )

In addition to the toxic diatoms, there were a number of species of the diatom genus Chaetoceros with long barbed spines which 

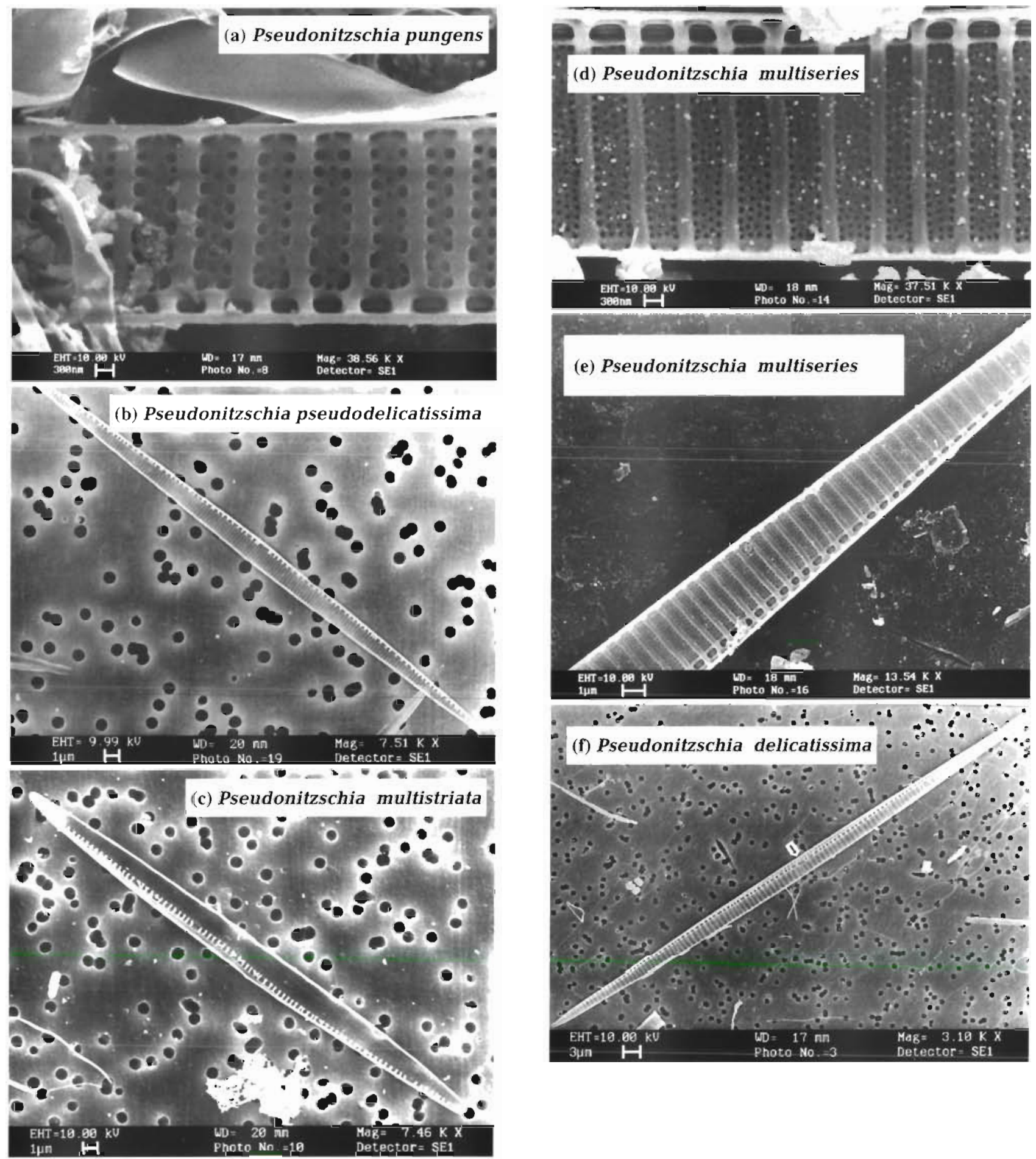

Fig. 5. Scanning electron micrographs of (a) Pseudonitzschia pungens; (b) P. pseudodelicatissima; (c) P. multistriata; (d) P. multiseries; (e) P. multiseries; and (f) P. delicatissima

cause mechanical damage to fish and invertebrate gills (Bell 1961). Blooms of these species pose an economic threat to finfish and shellfish fisheries (Shumway 1992). C. decipiens and C. concavicornis were identi- fied in OHBW, but never found in OOBW. C. concavicornis has not been reported for Hong Kong waters (Zhang 1997). The gills of Atlantic saimon have been shown to become clogged with mucus following a 


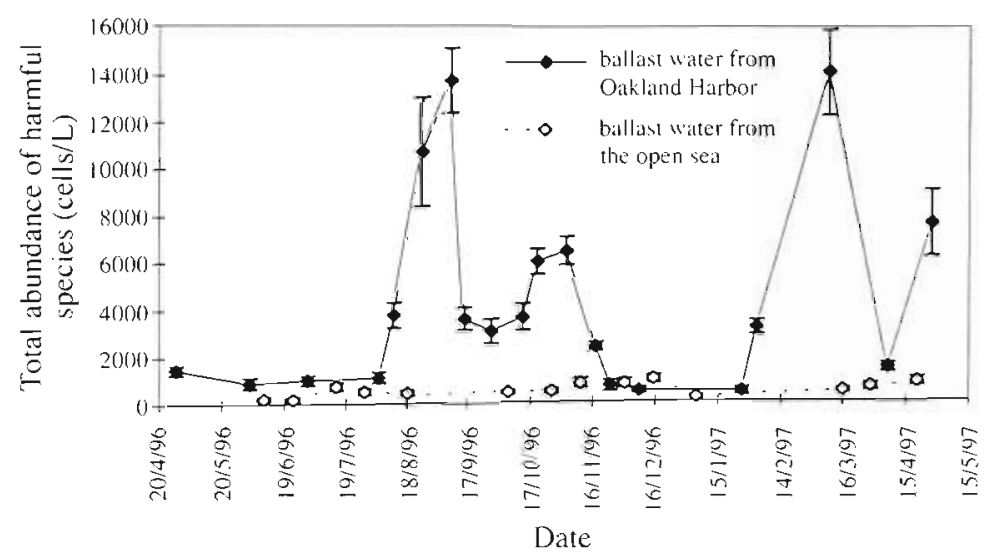

Fig. 6. Seasonal changes in the number of harmful species transported in the water in ballast tank no. 1 from Oakland Harbor and from the open ocean during the year-long study. Dates given as $\mathrm{d} / \mathrm{mo} / \mathrm{yr}$

bloom of $C$. concavicornis. These mucus clogged gills resulted in a deficiency of oxygen in the tissues and an excessive amount of carbon dioxide in the blood (Rensel 1993). C. concavicornis is a cold water species and is unlikely to colonise Hong Kong waters.

A third group of harmful diatoms have neither toxins nor spines: however, the decay of dense blooms of these diatoms can lower the dissolved oxygen concentrations in the water to the point that the resulting dissolved oxygen levels may lead to hypoxia (Richardson 1997). Skeletonema costatum has been reported to produce anoxic or hypoxic conditions in the nutrient enriched coastal waters of many parts of the globe (ICES 1992). Skeletonema costatum was the most common diatom from OHBW and OOBW observed in this study.

\section{Harmful dinoflagellates}

Alexandrium catenella, Dinophysis caudata, Gymnodinium sp., Prorocentrum balticum and P. sigmoides were identified in OHBW, but never found in OOBW.

Alexandrium catenella was found in $50 \%$ of OHBW, but the concentrations were low (Fig. 4). The maximum concentration of $A$. catenella was found at the end of April 1996. Temperatures in Hong Kong in the winter are similar to the cold temperate waters where this species is widely distributed. If this species was introduced into Hong Kong in winter, it is possible that it could establish itself in its new environment because its physiological requirements are met by conditions found in winter in Hong Kong.

The first dinoflagellate to be linked to PSP was Alexandrium catenella, which killed 6 people and made 102 people ill in 1927 near San Francisco (Dale \& Yentsch 1978). A. catenella is widely distributed in cold temperate waters, including the west coast of North America from California to Alaska. It has also been observed in the waters of Japan, Chile, Argentina and Australia (Taylor et al. 1995). There was no record of this species in Hong Kong waters until the 1980s (Ho \& Hodgkiss 1993). The mode of introduction of this species into Hong Kong waters is still not totally clear. Ho \& Hodgkiss (1993) suggested that this species was introduced by oceanic currents from Japan. However, it is also possible that this species could have been introduced into Hong Kong waters via ballast water. It is now believed that $A$. catenella was introduced into Australian waters from Japan through ballast water transport in the last 10 to 20 yr (Hallegraeff \& Bolch 1992, Scholin \& Anderson 1996). In our study, mid-ocean exchange appeared effective in eliminating this toxic dinoflagellate as there was no evidence of this species in any of our 14 samples from OOBW.

OOBW did contain a few harmful dinoflagellate species such as Ceratium fusus and Prorocentrum micans, indicating that mid-ocean exchange is not $100 \%$ effective in eliminating harmful dinoflagellates.

\section{Effectiveness of mid-ocean exchange (reballasting)}

Williams et al. (1988) suggested that mid-ocean exchange was an effective way to reduce the number of zooplankton species in ballast water. The present study concentrated on the effectiveness of mid-ocean exchange in reducing the number of harmful diatoms and dinoflagellate phytoplankton species. On average, the abundance of harmful phytoplankton in OOBW was $87 \%$ lower than in OHBW.

It is estimated that about 95 to $99 \%$ of the original ballast water from the OOCL ships' ballast tanks was removed during the mid-ocean reballasting in calm conditions (Captain Li Wai Man pers. comm.). The residual ballast water ( 1 to $5 \%$ ) contains an unknown proportion of organisms initially taken on during the coastal water ballasting (Locke et al. 1993, Rigby \& Hallegraeff 1993).

Many planktonic organisms observed by Rigby \& Hallegraeff (1993) in the mid-ocean ballast water were associated with waters withdrawn from near the bottom of the ballast tanks. These authors concluded that older ships accumulated a larger amount of sediment in the bottom of their ballast tanks than newer ships. The OOCL ships involved in this study had only been in use for about $1 \mathrm{yr}$ at the time this study began. These new OOCL ships were designed to eliminate as much 
sediment as possible from their ballast tanks during pumping. They employed large inverted funnelshaped ballast water discharge pipes, with the funneled intake located within a decimetre of the bottom of the ballast tanks. This design greatly reduces the amount of sediment accumulating in the bottom of ballast tanks, and hence results in a higher effectiveness of ballast water exchange. Hallegraeff \& Bolch (1992) observed that after mid-ocean exchange 14 of 32 vessels still contained significant amounts of sediment and this sediment contained large numbers of dinoflagellate cysts.

Locke et al. (1993) reported that mid-ocean exchange of ballast water was 67 to $86 \%$ effective in eliminating brackish-water-tolerant organisms common to coastal areas. In their study, they calculated the effectiveness according to the number of brackishwater-tolerant organisms found in the ballast water after mid-ocean exchange. This was premised on the assumption that no brackish-water-tolerant species are found in the open ocean. In our study, an estimate of open ocean exchange effectiveness was based on the percentage reduction of harmful species. A comparison of total species abundance and total harmful species abundance in the ballast water with or without mid-ocean exchange was made. In our study, midocean exchange decreased the total abundance of harmful species, on average, from 4235 to 550 cells $l^{-1}$ (Table 2, Fig. 6).

Our approach avoids the difficult job of assigning each species to 1 of 2 categories: tolerant or intolerant of low salinity. Assigning species to tolerant or intolerant of low salinity categories is difficult because there are a number of species which are classified as euryhaline, i.e these species tolerate a wide range of salinity, making it difficult to determine whether such species originally came from the open ocean or from coastal waters. There are also a number of species for which we have very limited information regarding salinity range.

\section{Conclusions}

Our study of 20 ships with Oakland water and 14 ships with open ocean water is the first year-long seasonal study to assess the effectiveness of mid-ocean exchange of ballast waters. The number and total abundance of harmful diatoms and dinoflagellates in the ballast water from Oakland were significantly higher than those in the ballast water from the open ocean. Mid-ocean exchange of ballast water (reballasting) was $87 \%$ effective in controlling harmful dinoflagellates and diatoms. However, it did not eliminate all harmful organisms because of the incomplete dis- charge of water and sediments in the ballast tank during mid-ocean exchange.

As expected, major changes in the abundance of harmful diatoms and dinoflagellates were observed. Most harmful dinoflagellates reached their peak abundances in Oakland Harbor ballast water during winter and spring, while the most abundant diatom, Skeletonema costatum, reached peak abundance in spring and summer.

Acknowledgements. We are gratetul to the Orient Overseas Container Lines Ltd (OOCL) Hong Kong for their co-operation and assistance during this study and to Mr Lambros Bakountouzis of the University of Hong Kong Mechanical Engineering Dept for designing and installing the flowmeter so that exactly $100 \mathrm{l}$ of water would pass from the ballast tank into our $10 \mu \mathrm{m}$ mesh plankton net. Mr Bakountouzis also made the initial contact with OOCL. The Electron Microscope Unit of the University of Hong Kong made its SEM available to us so we could better identify some of our species. We are also grateful to The University of Hong Kong for the studentship support provided to the first author.

\section{LITERATURE CITED}

Bell GR (1961) Penetration of spines from a marine diatom into the gill tissue of lingcod (Ophidon elongatus). Nature 192:279-280

Carlton JT (1985) Transoceanic and interoceanic dispersal of coastal marine organisms: the biology of ballast water. Oceanogr Mar Biol Annu Rev 23:313-371

Carlton JT, Geller B (1993) Ecological roulette: the global transport of non-indigenous marine organisms. Science 261:78-82

Cheng Z, Gao Y, Dickman MD (1996) Colour plates of the diatoms. China Ocean Press, Beijing

Chu KH, Tam PF, Fung CH, Chen QC (1997) A biological survey of ballast water in container ships entering Hong Kong. Hydrobiologia 352:201-206

Dale B. Yentsch CM (1978) Red tide and paralytic shellfish poisoning. Oceanus 21:41-49

Dickman MD (1996) A search for domoic acid producing diatoms in Hong Kong waters. In: Yasumoto T, Oshima $Y$, Fukuyo $Y$ (eds) Harmful and toxic algal blooms. Proc 7 th Int Conf Toxic Phytoplankton, Sendai. Intergovernmental Oceanographic Commission of UNESCO. UNESCO, Paris p $159-162$

Dickman MD, Glenwright $T$ (1997) A comparison of marine planktonic and sediment core diatoms in Hong Kong with emphasis on Pseudo-nitzschia. Hydrobiologia 352:149-158

Dickman MD, Qi Y, Zheng L (1997) Toxic diatoms belonging to the genus Pseudonitzschia from the coast of southern China. In: Saxena NK (ed) Proc Pac Congr Mar Sci Technol. PACON International, Honolulu, p 434

Fukuyo Y, Takano H, Chihara M, Matsuoka K (1990) Red tide organisms in Japan-an illustrated taxonomic guide. Uchida Rokakuho, Tokyo

Garrison DL, Conrad SM, Ellers PP, Waldron M (1992) Confirmation of domoic acid production by Pseudonitzschia australis (Bacillariophyceae) cultures. J Phycol 28:604-607

Gosselin S, Levasseur M, Gautheir D (1995) Transport and deballasting of toxic dinoflagellates via ships in the Grande Entée Largoon of the Illes-de-Ia-Madeleine (Gulf 
of St. Lawrence. Canada). In: Lassus P. Arzul G, Erad E, Gentien P. Marcaillou C (eds) Harmful marine algal blooms. Lavoisier/Intercept, Paris, p 591-596

Hallegraeff GM (1991) Aquaculturists' guide to harmful australian microalgae. CSIRO Division of Fisheries, Hobart

Hallegraeff GM, Bolch CJ (1992) Transport of diatom and dinoflagellate resting spores in ships' ballast water: implications for plankton biography and aquaculture. J Plankton Res 14:1067-1084

Hasle GR (1994) Pseudo-nitzschia as a genus distinct from Nitzschia (Bacillariophyceae). J Phycology 30:1036-1039

Hasle GR, Fryxell GA (1995) Taxonomy of diatoms. In: Hallegraeff GM, Anderson DM, Cembella AD (eds) Manual on harmful marine microalgae. UNESCO, IOC: Manual and Guides 33:339-364

Haya $K$, Martin JL, Burridge LE, Waiwood BA, Wildfish DJ (1991) Domoic acid in shellfish and plankton from the Bay of Fundy, New Brunswick, Canada. J Shellfish Res 10: $113-118$

Hebert PD, Muncaster NBW, Mackie GL (1989) Ecological and genetic studies on Dreissena polymorpha (Pallas): a new mollusc in the Great Lakes. Can J Fish Aquat Sci 46: $1587-1591$

Ho KC, Hodgkiss IJ (1993) Characteristics of red tides caused by Alexandrium catenella (Whedon \& Kofoid) Balech in Hong Kong. In: Smayda TJ, Shimizu Y (eds) Toxic phytoplankton blooms in the sea. Elsevier Science Publishing Co, Amsterdam, p 263-268

Hutchings P (1992) Ballast water introductions of exotic marine organisms into Australia: current status and management options. Mar Pollut Bull 25:196-199

ICES (1992) Report of the working group on effects of harmful algal blooms on mariculture and marine fisheries. International Council Meeting Paper 1992/No. 181

Jin DX, Cheng ZD, Lin JM, Liu SC (1985) Marine benthic diatoms in China (I). China Ocean Press, Beijing

Jin DX, Cheng ZD, Lin JM, Liu SC (1992) Marine benthic diatoms in China (II). China Ocean Press, Beijing (in Chinese)

Jones MM (1991) Marine organisms transported in ballast water. A review of the Australian scientific position. Bureau of Rural Resources Bulletin, 11 Australian Government Printing Service, Canberra

Larsen J, Moestrup $\varnothing$ (1989) Guide to toxic and potentially toxic marine algae. The Fish Inspection Service, Ministry of Fisheries, Copenhagen

Locke AD, Reid M, Van Leeuwen HC, Sprules WG, Carlton JT (1993) Ballast water exchange as a means of controlling dispersal of freshwater organisms by ships. Can J Fish Aquat Sci 50:2086-2093

McCarthy S, Khambaty FM (1994) International dissemination of epidemic Vibrio cholerae by cargo ship ballast and other nonpotable waters. Appl Environ Microbiol 60: $2597-2601$

Mills EL, Leach JH, Carlton JT, Sector CL (1993) Exotic species in the Great Lakes: a history of biotic crises and anthropogenic introductions. Great Lakes Res 19:1-54

Rensel JE (1993) Severe bloom hypoxia of Atlantic salmon (Salmo salar) exposed to the marine diatom Chaetoceros concavicornis. In: Smayda TJ, Shimizu Y (eds) Toxic phytoplankton blooms in the sea. Elsevier Science Publishing Co, Amsterdam, p 625-630

Richardson K (1997) Harmful or exceptional phytoplankton

Editorial responsibility: Otto Kinne (Editor),

Oldendorf/Luhe, Germany blooms in the marine ecosystem. Adv Mar Biol 31:302-385 Rigby GR, Hallegraeff GM (1993) Shipping ballast water trials on the bulk carrier $M$. V. Iron. Whyalla. AQIS Ballast Water Research Series, Report No. 2, Australian Government Publishing Service, Canberra

Rigby GR, Hallegraeff GM (1996) Ballast water controls to minimise the translation and establishment of toxic marine phytoplankton - what progress have we made and where are we going? In: Yasumoto T. Oshima Y, Fukuyo Y (eds) Harmful and toxic algal blooms. Intergovernmental Oceanographic Commission of UNESCO 1996. UNESCO, Paris, p 201-204

Rigby GR, Steverson IG, Bolch CJ, Hallegraeff GM (1993) The transfer and treatment of shipping ballast waters to reduce the dispersal of toxic marine dinoflagellates. In: Smayda TJ, Shimizu Y (eds) Toxic phytoplankton blooms in the sea. Elsevier Science Publishing Co, Amsterdam, p $169-176$

Rigby GR, Taylor AH, Hallegraeff GM, Mills P (1995) Progress in research and management of ships' ballast water to minimise the transfer of toxic dinoflagellates. In Lassus P, Arzul G, Erard E, Gentien P, Marcaillow C (eds) Harmful marine algal blooms. Lavoisier/Intercept, Paris, p $821-824$

Ruiz GM, Carlton JT, Grosholz ED, Hines AH (1997) Global invasions of marine and estuarine habitats by non-indigenous species: mechanisms, extent and consequences. Am Zool 37:621-632

Scholin CA, Anderson DM (1996) Identification of Alexandrium species and strains using RFLP analysis of PCRamplified LSU rDNA. Harmful and toxic algal blooms. In: Yasumoto T, Oshima Y, Fukuyo Y (eds) Harmful and toxic algal blooms. Proc 7th Int Conf Toxic Phytoplankton, Sendai. Intergovernmental Oceanographic Commission of UNESCO, Paris, p 451-454

Shumway SE (1992) A review of the effects of algal blooms on shellfish and aquaculture. J Shellfish Res 11:556

Siu KY (1995) An investigation on a red tide dinoflagellate, Alexandrium catenella-physiology, occurrence and toxicity. PhD thesis, Zoology Dept, The University of Hong Kong

Taylor FJR, Fukuyo Y, Larsen L (1995) Taxonomy of harmful dinoflagellates. In: Hallegraeff GM, Anderson DM, Cembella $A D$ (eds) Manual on harmful marine microalgae UNESCO, IOC Manual and Guides 33:283-316

Thompson Clarke Shipping (1993) Ballast water management. A.QIS Ballast Water Research Series, Report No. 4 Australian Government Publishing Service, Canberra

Tomas CR (1996) ldentifying marine diatoms and dinoflagellates. Academic Press, San Diego

Villac MC, Roelke DL, Villareal TA, Fryxell GA (1993) Comparison of two domoic acid-producing diatoms: a review Hydrobiologia 269/270:213-224

Williams RJ, Griffiths FB, Van der Wal EJ, Kelly J (1988) Cargo vessel ballast water as a vector for the transport of non-indigenous marine species. Estuar Coast Shelf Sci 26 $409-420$

Yamaji I (1984) Illustrations of the marine plankton of Japan. Hoikusha, Osaka

Zhang F (1997) Harmful algae from container ship ballast water taken from the open ocean and from Oakland, California (May 1996 to April 1997). M Phil thesis, Ecology and Biodiversity Dept, The University of Hong Kong

Submitted: February 16, 1998; Accepted: July 31, 1998

Proots received from author(s): December 28, 1998 